\title{
Correction to: Teachers responding to cultural diversity: case studies on assessment practices, challenges and experiences in secondary schools in Austria, Ireland, Norway and Turkey
}

\author{
Barbara Herzog-Punzenberger ${ }^{1,2} \cdot$ Herbert Altrichter $^{1}$ (D) Martin Brown $^{3}$. \\ Denise Burns ${ }^{3}$. Guri A. Nortvedt ${ }^{4}$. Guri Skedsmo ${ }^{4,5}$. Eline Wiese ${ }^{4}$. \\ Funda Nayir ${ }^{6} \cdot$ Magdalena Fellner $^{7} \cdot$ Gerry McNamara $^{3} \cdot$ Joe O$^{\prime}$ Hara $^{3}$
}

(C) Springer Nature B.V. 2020

\section{Correction to: Educational Assessment, Evaluation and Accountability https://doi.org/10.1007/s11092-020-09330-y}

The original version of this article unfortunately contained a mistake. The text in the online first version of the paper on page 2 reads as follows:

The initial conceptualisation for this research — which was part of a three-year European Union-funded project entitled Aiding Culturally Responsive Assessment in Schools (ACRAS) [1] [1] ERASMUS+-Project 'Aiding Cultural Responsive Assessment in Schools' (ACRAS; 2016-1-IE01-KA201-016889)—came from studying how teachers cope with and adapt to the assessment needs of culturally diverse classrooms

This text should be changed to the following version:

The initial conceptualisation for this research - which was part of a three-year European Union-funded project entitled Aiding Culturally Responsive Assessment in Schools (ACRAS) ${ }^{1}$ — came from studying how teachers cope with and adapt to the assessment needs of culturally diverse classrooms.

\footnotetext{
${ }^{1}$ ERASMUS+-Project 'Aiding Cultural Responsive Assessment in Schools' (ACRAS; 2016-1-IE01-KA201016889)
}

The online version of the original article can be found at https://doi.org/10.1007/s11092-020-09330-y

\section{Herbert Altrichter}

herbert.altrichter@jku.at

Extended author information available on the last page of the article 
Publisher's note Springer Nature remains neutral with regard to jurisdictional claims in published maps and institutional affiliations.

\section{Affiliations}

Barbara Herzog-Punzenberger ${ }^{1,2} \cdot$ Herbert Altrichter ${ }^{1}$ - Martin Brown ${ }^{3}$ • Denise Burns $^{3} \cdot$ Guri A. Nortvedt ${ }^{4}$. Guri Skedsmo ${ }^{4,5}$ • Eline Wiese ${ }^{4}$. Funda Nayir ${ }^{6}$. Magdalena Fellner ${ }^{7}$. Gerry McNamara ${ }^{3} \cdot$ Joe O'Hara $^{3}$

Barbara Herzog-Punzenberger

barbara.herzog-punzenberger@uibk.ac.at

Martin Brown

martin.brown@dcu.ie

Denise Burns

denise.burns@dcu.ie

Guri A. Nortvedt

guri.nortvedt@ils.uio.no

Guri Skedsmo

guri.skedsmo@ils.uio.no

Eline Wiese

e.f.wiese@ils.uio.no

Funda Nayir

fnayir09@gmail.com

Magdalena Fellner

magdalena.fellner@donau-uni.ac.at

Gerry McNamara

gerry.mcnamara@dcu.ie

Joe O'Hara

joe.ohara@dcu.ie

1 Linz School of Education, Johannes Kepler University, Linz, Austria

2 University of Innsbruck, Innsbruck, Austria

3 Dublin City University, Dublin, Ireland

4 University of Oslo, Oslo, Norway

5 Schwyz University of Teacher Education, Goldau, Switzerland

6 Pamukkale University, Denizli, Turkey

7 Danube University Krems, Krems an der Donau, Austria 